\title{
Study of various adsorbent-refrigerant pairs for the application of solar driven adsorption cooling in tropical climates
}

\author{
Khairul Habib ${ }^{a}$, Bidyut Baran Saha ${ }^{\text {b,c,* }}$, and Shigeru Koyama ${ }^{\text {b,c }}$ \\ ${ }^{a}$ Department of Mechanical Engineering, University Technology Petronas \\ Bandar Seri Iskander 31750 Tronoh, Perak Darul Ridzuan, Malaysia \\ ${ }^{b}$ Interdisciplinary Graduate School of Engineering Sciences, Kyushu University \\ 6-1 Kasuga-koen, kasuga-shi Fukuoka 816-8580, Japan \\ ${ }^{c}$ International Institute for Carbon-Neutral Energy Research (WPI-I2CNER), Kyushu University \\ 744 Motooka, Nishi-ku, Fukuoka 819-0395, Japan \\ *Corresponding author, E-mail address: saha.baran.bidyu.213t@m.kyushu-u.ac.jp \\ Tel: +81-92-583-7903, Fax: +81-92-583-8909
}

\begin{abstract}
This article presents analytical investigation results on the performance of solar powered adsorption cooling systems for Malaysia and similar tropical regions. The studied adsorbentrefrigerant pairs are silica gel-water, activated carbon fiber-ethanol and activated carbonmethanol. A computer simulation program has been developed for modeling and performance evaluation for the solar driven adsorption cooling cycle using the meteorological data of Kuala Lumpur, Malaysia The simulation is based on the experimentally confirmed adsorption isotherms, kinetics and isosteric heat of the adsorption data for the respective adsorbentrefrigerant pairs. The optimum cooling capacity and coefficient of performance (COP) of the different adsorbent-refrigerant pairs varying adsorption-desorption cycle time, regeneration temperature and chilled water inlet temperature are calculated and compared.
\end{abstract}


Keywords: activated carbon; adsorption; cooling; silica gel; solar thermal

\section{Nomenclature}

Symbols

$\alpha_{0} \quad$ coefficient in equation (1) [ $\left.\mathrm{kg}(\mathrm{kg} \text { of dry adsorbent })^{-1}\right]$

$\alpha_{1} \quad$ coefficient in eq. (1) [ $\left.\mathrm{kg}(\mathrm{kg} \text { of dry adsorbent, } \mathrm{K})^{-1}\right]$

$\alpha_{2} \quad$ coefficient in eq. (1) [ $\left.\mathrm{kg}\left(\mathrm{kg} \text { of dry adsorbent, } \mathrm{K}^{2}\right)^{-1}\right]$

$\alpha_{3} \quad$ coefficient in eq. (1) $\left[\mathrm{kg}\left(\mathrm{kg} \text { of dry adsorbent, } \mathrm{K}^{3}\right)^{-1}\right]$

$\beta_{0} \quad$ coefficient in eq. (1) [-]

$\beta_{1} \quad$ coefficient in eq. (1) $\left[\mathrm{K}^{-1}\right]$

$\beta_{2} \quad$ coefficient in eq. (1) $\left[\mathrm{K}^{-2}\right]$

$\beta_{3} \quad$ coefficient in eq. (1) $\left[\mathrm{K}^{-3}\right]$

A $\quad$ area $\left[\mathrm{m}^{2}\right]$

$A_{\mathrm{c}} \quad$ collector area $\left[\mathrm{m}^{2}\right]$

COP coefficient of performance [-]

$C_{p} \quad$ specific heat capacity $[\mathrm{J} / \mathrm{kg}-\mathrm{K}]$

$D_{s} \quad$ surface diffusion coefficient $\left[\mathrm{m}^{2} / \mathrm{s}\right]$

$D_{s o} \quad$ pre-exponential constant $\left[\mathrm{m}^{2} / \mathrm{s}\right]$

$E_{a} \quad$ activation energy $[\mathrm{J} / \mathrm{kg}]$

$h \quad$ enthalpy $[\mathrm{J} / \mathrm{kg}]$

$M \quad$ mass $[\mathrm{kg}]$ 


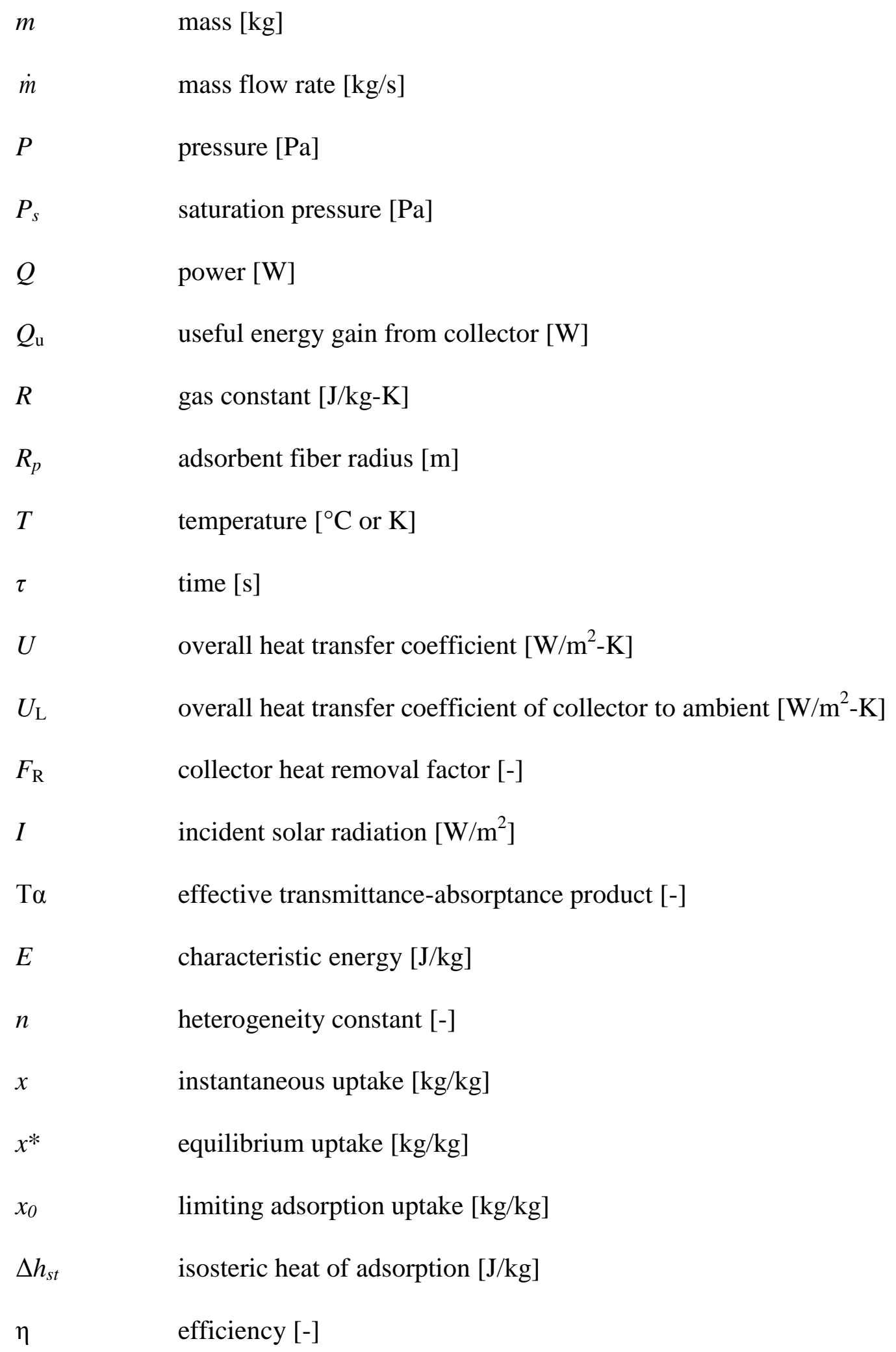




$\begin{array}{ll}\text { Subscripts } & \\ \text { sg } & \text { silica gel } \\ f & \text { liquid phase } \\ a & \text { adsorbent } \\ g & \text { gaseous phase } \\ \text { in } & \text { inlet } \\ \text { out } & \text { outlet } \\ w & \text { water } \\ \text { bed } & \text { sorption heat exchanger (adsorber/desorber) } \\ \text { col } & \text { collector } \\ \text { amb } & \text { ambient }\end{array}$

Superscripts

ref refrigerant

\section{Introduction}

Thermally powered sorption cooling systems have attracted much attention as they appear to be promising from the view point of greenhouse gas emissions and ozone layer depletion problems [1]. Chlorofluorocarbons (CFCs) and Hydro-chlorofluorocarbons (HCFCs) have been considered as the major contributors to the environmental hazard. Thermally driven adsorption based chillers have zero ozone depletion potential due to the use of natural and/or alternative refrigerants like water, ammonia, methanol, ethanol, etc. As solar energy or low grade waste 
heat can be effectively utilized to run these systems, it has the potential to reduce the peak load demand of electricity and the emission of greenhouse gases as well. The other advantages of adsorption refrigeration systems are that they are free of vibrations as they do not have any moving parts, simple control and lower operation cost. Thermally powered adsorption cooling cycle could be operated in both partial vacuum and pressurized conditions. The adsorbentrefrigerant pairs working at sub-atmospheric conditions are silica gel-water [1, 2], zeolite-water $[3,4]$, activated carbon fiber-ethanol [5, 6], activated carbon-methanol [7, 8], etc.

Solar adsorption refrigeration system seems to be a promising alternative refrigeration device since cooling load of buildings is roughly in phase with solar energy availability. During the past decades much research has been performed on solar adsorption refrigeration. Table 1 lists solar driven adsorption refrigeration systems using various adsorbent-refrigerant pairs.

The present study introduces a comparison of solar driven adsorption cooling systems using the meteorological data of Kuala Lumpur. A cycle simulation computer program has been developed to analyze cooling capacity and COP by varying adsorption/desorption cycle time, regeneration temperature and chilled water inlet temperature. Performance data of silica gelwater, activated carbon fiber-ethanol and activated carbon-methanol based adsorption systems have been presented and compared. The results obtained from this analysis will be useful in selecting a suitable adsorbent-refrigerant pair for adsorption cooling in tropical climates.

\section{Working principle of the solar adsorption chiller}

In the present study, a two bed solar powered adsorption cooling cycle has been studied. The schematic diagram of the adsorption cycle is shown in the Figure 1. The chiller is composed of four heat exchangers namely two adsorber/desorber heat exchangers, an evaporator and a 
condenser. Four refrigerant valves are used for the operation four pre-determined processes namely, adsorption, pre-heating, desorption and pre-cooling. As can be seen from Fig. 1, refrigerant evaporates from the evaporator and adsorbed by the adsorber bed through refrigerant valve V4. At the same time desorbed refrigerant goes to the condenser through refrigerant valve V2 which is known as the desorption-condensation process. The desorber bed is powered by solar thermal heat which is the only heat source of the studied system. The details of the working principle of adsorption chiller have been described in detail elsewhere [1].

\section{Adsorbent-refrigerant pair}

In the present study, three different adsorbent-refrigerant pairs have been selected and these are silica gel-water, activated carbon fiber (ACF)-ethanol and activated carbon (AC)-methanol. The porous properties of silica gel, ACF and AC are listed in Table 2. It is evident from Table 2 that ACF possesses largest surface area which is followed by activated carbon. ACF also has higher adsorption capacity than the other two studied adsorbents. On the other hand, silica gel has higher apparent density compared to ACF and AC, which indicates that it is easier to pack relatively larger amount of silica gel into the adsorbent bed of the silica gel-water based adsorption chiller.

\section{Mathematical modeling}

\subsection{Adsorption kinetics}

Adsorption rates of silica gel-water, ACF-ethanol and AC-methanol pairs are estimated from the linear driving force equation.

$$
\frac{d x}{d \tau}=15 \frac{D_{s 0} \exp \left(-\frac{E_{a}}{R T}\right)}{R_{p}^{2}}(x *-x)
$$


The numerical values of $D_{\text {so }}$ and $E_{a}$ for silica gel water [1], ACF-ethanol [5] and AC-methanol [26] are evaluated experimentally.

\subsection{Adsorption isotherms}

For silica gel-water system, the S-B-K isotherm model [27], which is expressed by Eq. (2), is used to estimate the equilibrium uptake.

$$
x^{*}=\alpha\left(T_{s g}\right)\left[\frac{P_{s}\left(T^{r e f}\right)}{P_{s}\left(T_{s g}\right)}\right]^{\beta\left(T_{s g}\right)}
$$

Where,

$$
\begin{aligned}
& \alpha\left(T_{s g}\right)=\alpha_{0}+\alpha_{1}\left(T_{s g}\right)+\alpha_{2}\left(T_{s g}\right)^{2}+\alpha_{3}\left(T_{s g}\right)^{3} \\
& \beta\left(T_{s g}\right)=\beta_{0}+\beta_{1}\left(T_{s g}\right)+\beta_{2}\left(T_{s g}\right)^{2}+\beta_{3}\left(T_{s g}\right)^{3}
\end{aligned}
$$

The Dubinin- Radushkevich (D-R) equation is used to estimate the equilibrium uptake of ACF ethanol pair.

$$
x^{*}=x_{0} \exp \left[-D\left\{T \ln \left(\frac{P_{s}}{P}\right)\right\}^{2}\right]
$$

Dubinin-Astakhov (D-A) model is used to estimate the uptake of AC-methanol pair.

$$
x^{*}=x_{0} \exp \left[-D\left\{T \ln \left(\frac{P_{s}}{P}\right)\right\}^{n}\right]
$$

Table 3 lists the numerical values of $\alpha_{0}$ to $\alpha_{3}$ and $\beta_{0}$ to $\beta_{3}$ of silica gel-water pair, $x_{0}$ and $D$ for ACF-ethanol pair and $x_{0}, D$ and $n$ for AC-methanol pair. 


\subsection{Solar collector energy balance}

The energy balance of the energy balance of the evacuated tube collector can be expressed as, $\dot{m} C_{p f}\left(T_{\text {out }}-T_{\text {in }}\right)=A_{c} F_{R}\left[I(\tau \alpha)-U_{L}\left(T_{\text {in }}-T_{\text {amb }}\right)\right]$

The left hand side of eq. (5) indicates energy output from the collector. The first term of the right hand side of eq. (5) represents energy recovery from the collector and the second term shows the energy loss from the collector.

Thus the instantaneous collector efficiency at steady state can be defined as the ratio of the useful energy output to the product of solar radiation and collector surface area.

$\eta_{c o l}=\frac{Q_{u}}{I A_{c}}=\frac{F_{R}\left[I(\tau \alpha)-U_{L}\left(T_{i n}-T_{a m b}\right)\right]}{I}$

\subsection{Adsorption and desorption energy balance}

Using the lumped approach, the energy balance for the sorption bed of three various adsorbent/refrigerant pairs can be expressed as [5]

$\left[m_{a}\left(C_{p, a}+C_{p}^{r e f} x\right)+m_{h e x} C_{p, h e x}\right] \frac{d T_{b e d}^{r e f}}{d \tau}=m_{a} \Delta h_{s t} \frac{d x_{b e d}^{r e f}}{d \tau}+m_{a} C_{p, v}^{r e f} \frac{d x_{b e d}^{r e f}}{d \tau}+\dot{m}_{f} C_{p, f}\left(T_{b e d, \text { in }}-T_{b e d, o u t}\right)$

where $\gamma=1$ for reactor working as adsorber, and $\gamma=0$ for reactor working as desorber. The left hand side of adsorber/desorber energy balance equation (Eq. 7) indicates the rate of change of internal energy due to the thermal mass of adsorbent(s), the refrigerant and adsorber /desorber heat exchanger during adsorption and desorption. The first term on the right hand side of Eq. (7) represents the adsorption or desorption heat, the second term for energy transport due to refrigerant vapor transfer from evaporator to adsorbent bed during adsorption-evaporation process. The third term on Eq. (7) defines the total amount of heat released to the cooling water 
upon adsorption or provided by the heating source (hot water) for desorption. For a small temperature difference across heating/cooling fluid such as water, the outlet temperature of the heat source or heat sink is sufficiently accurate to be modeled by the log mean temperature difference (LMTD) method and it is given by:

$\frac{T_{b e d, o u t}-T_{b e d}}{T_{b e d, \text { in }}-T_{\text {bed }}}=\exp \left[-\frac{(U A)_{\text {bed }}^{r e d}}{\dot{m}_{f} C_{p, f}}\right]$

Similarly condenser and evaporator energy balances can be obtained.

The cooling capacity, $Q_{\text {eva }}^{\text {cycle }}$ of this can be defined as,

$$
Q_{\text {eva }}^{\text {cycle }}=\frac{1}{\tau_{\text {cycle }}} \int_{0}^{\tau_{\text {cycle }}}\left(\dot{m} C_{p}\right)_{w}\left(T_{\text {chill, in }}-T_{\text {chill,out }}\right) d \tau
$$

The driving source temperature can be expressed as,

$Q_{\text {hot }}^{\text {ref }}=\frac{1}{\tau_{\text {cycle }}} \int_{0}^{\tau_{\text {ovle }}}\left(\dot{m} C_{p}\right)_{\text {des }}\left(T_{\text {hot, in }}-T_{\text {hot,out }}\right) d \tau$

Here $\tau_{\text {cycle }}$ denotes total cycle time.

The coefficient of performance (COP) can be obtained as,

$$
C O P=\frac{Q_{h o t}^{r e f}}{Q_{\text {eva }}^{\text {cycle }}}
$$

\section{Weather data}

An accurate climatic database is required for the performance evaluation of solar powered energy conversion technologies. In this regard, the accuracy of solar radiation and ambient air temperature is crucial. The climatic data based on the typical year concept for Kuala Lumpur, 
Malaysia $\left(3.16^{\circ} \mathrm{N}, 101.7^{\circ} \mathrm{E}\right)$ have been used in the present study. Figure 2 shows the variation of hourly average global solar radiation of Kuala Lumpur on a particular day [29]. It can be seen from Fig. 2 that the highest solar radiation on a particular day is about $650 \mathrm{~W} / \mathrm{m}^{2}$ which is obtained at around noon.

\section{Results and discussion}

\subsection{Hot water supply}

Figure 3 depicts the variation of the hot water storage tank temperature for Kuala Lumpur climate throughout a day three years back from now (1st May, 2011). Hot water temperature from tank never falls below $60^{\circ} \mathrm{C}$ because of the automatic operation of the auxiliary heater. It can be seen from Fig. 3 that during noon the maximum temperature of the hot water is achieved, which is around $88^{\circ} \mathrm{C}$.

\subsection{Ideal cooling cycle}

Using the isotherm data, the conceptual ideal adsorption cooling systems of silica gel-water, ACF-ethanol and AC-methanol pairs are illustrated in Figure 4. One can understand from Fig. 4 that for the same operating temperature conditions, the difference between the maximum and minimum uptake $\left\{\Delta x=x_{\max }-x_{\min }\right\}$ of ACF-ethanol cycle is higher than that of AC-methanol and silica gel-water cycles. The $\Delta x$ values for ACF-ethanol cycle is $0.44 \mathrm{~kg} / \mathrm{kg}$, which is followed by AC-methanol and silica gel-water cycles $(0.4 \mathrm{~kg} / \mathrm{kg}$ and $0.08 \mathrm{~kg} / \mathrm{kg})$, respectively. 


\subsection{Adsorption /desorption cycle time}

Table 4 shows the rated conditions for silica gel-water, ACF-ethanol and AC-methanol based adsorption cooling cycles. The values adopted in the present simulation model are furnished in Table 5. The simulated results of cooling capacity variations with adsorption/desorption cycle time for adsorption cooling cycle of the studied pairs are depicted in Fig. 5. The switching (preheating or pre-cooling) time is chosen as $50 \mathrm{~s}$. As can be seen from Fig. 5, when the cycle time is smaller than $400 \mathrm{~s}$, adsorption or desorption cannot occur sufficiently. As a result, cooling capacity decreases abruptly. On the other hand, when cycle time is longer than $700 \mathrm{~s}$, the cooling capacity decreases gradually due to the less intense of adsorption after the first 10 minutes as the adsorbent reaches towards equilibrium. From Fig. 5 it is also observed that among the three studied systems, silica gel-water system has the highest cooling capacity, which is around $13 \mathrm{~kW}$ for the cycle time between 450 and $500 \mathrm{~s}$. But it is also noticeable that there is a sharp drop of cooling capacity of silica gel-water system when the cycle time is around 800s. The maximum cooling capacity of AC-methanol and ACF-ethanol systems are 11.5 and $11 \mathrm{~kW}$, respectively.

Figure 6 demonstrates the variation of COP with adsorption/desorption cycle time for the studied three pairs. It can be seen from Fig. 6 that the COP of all three pairs increase with the increase of adsorption/desorption cycle time. However, after $900 \mathrm{~s}$, the increase of COP values becomes marginal. It is also noticeable that ACF-ethanol system has the highest COP (around 0.62). The optimum values of COP for ACF-ethanol, silica gel-water and AC-methanol system are around $0.5,0.45$ and 0.43 , respectively when the cycle time is around $450-500 \mathrm{~s}$.

\subsection{Regeneration temperature}

Figure 7 shows the variation of cooling capacity of the studied three systems with driving heat source temperature supplied from the hot water storage tank for Kuala Lumpur climate 
conditions. Heat transfer fluid flow rates and cycle times are taken as the rated values which are shown in Table 3. It can be observed from Fig. 7 that the cooling capacities of all the three systems maintain a linear relationship with the driving heat source temperature. The relationship between cooling capacity and driving heat source temperature of zeolite-water based adsorption chiller is also shown in Fig. 7. The experimental results of zeolite-water based chiller are taken from Singapore climate conditions which are similar to those of Kuala Lumpur. From Fig. 7 it is

evident that the zeolite-water system has the highest cooling capacity followed by silica gelwater system, AC-methanol and ACF-ethanol system. The cooling capacity of silica gel-water system varies from 6 to $16 \mathrm{~kW}$ with the heat source temperature varies from 60 to $95^{\circ} \mathrm{C}$. This is due to the amount of refrigerant circulation increases when the amount of desorbed refrigerant increases with the higher driving heat source temperature.

The variation of COP with regeneration temperature for the four systems is depicted in Figure 8. It is observable from Fig. 8 that for Kuala Lumpur climate conditions, when the heat source temperature is below $70^{\circ} \mathrm{C}$, silica gel-water system has the highest value of COP which is around 0.5 which is followed by the COP values of ACF-ethanol and AC-methanol systems. But when the heat source temperature is more than $70^{\circ} \mathrm{C}$, the COP of ACF-ethanol system reaches up to around 0.55 . It is noticeable from Fig. 8 that the COP values of all three studied systems increase with increase in regeneration temperature until the temperature reaches $75^{\circ} \mathrm{C}$. After that the COP increases slightly with the increase in regeneration temperature.

\subsection{Chilled water inlet temperature}

The effects of chilled water inlet temperatures on cooling capacity of the studied three pairs are illustrated in Fig. 9. It can be observed from Fig. 9 that silica gel-water cycle has the highest 
cooling capacity varying from 12 to $19 \mathrm{~kW}$ when the chilled water temperature varies from 10 to $20^{\circ} \mathrm{C}$. The variation of COP with chilled water inlet temperatures is depicted in Fig. 10. It can be observed from Fig. 10 that ACF-ethanol has the highest COP varying from 0.5 to around 0.6, followed by AC-methanol and silica gel-water pairs.

\section{Conclusions}

The aim of the present study is to compare three different adsorption cooling cycles driven by solar thermal energy suitable for tropical climates. Meteorological data of Kuala Lumpur have been used in this study. The main conclusions are as follows:

i. ACF-ethanol cycle shows the highest adsorption uptake followed by AC-methanol and silica gel-water pairs.

ii. Simulation results indicate that for Kuala Lumpur climate, cooling capacity of silica gel water system is highest among the studied three different adsorbent-refrigerant pairs. For all three studied pairs, cooling capacity increases with the increase in cycle time.

iii. Silica gel-water cycle demonstrates the highest COP values when regeneration temperature is below $70^{\circ} \mathrm{C}$. However, the COP of ACF-ethanol based adsorption cycle is found to be highest when the regeneration temperature is above $70^{\circ} \mathrm{C}$.

iv. The present study may provide useful information in designing adsorption based cooling cycles for Malaysia and similar tropical regions. 


\section{Acknowledgements}

This work was financially supported by Japan Science and Technology Agency (JST), Core Research for Evolutional Science and Technology (CREST).

\section{References}

[1] H. T. Chua, K.C. Ng, A. Malek, T. Kashiwagi, A. Akisawa, B.B. Saha, Modeling the performance of two-bed silica gel-water adsorption chillers, International Journal of Refrigeration 22 (1999) 194-204.

[2] D. Wang, J. Zhang, Q. Yang, N. Li, K. Sumathy, Study of adsorption characteristics in silica gel-water adsorption refrigeration, Applied Energy 113 (2014) 734-741.

[3] A. Myat, K.C. Ng, K. Thu, Y-D. Kim, Experimental investigation on the optimal performance of zeolite-water adsorption chiller, Applied Energy 102 (2013)582-590.

[4] I. Solmus, B. Kaftanoglu, C. Yamali, D. Baker, Experimental investigation of a natural zeolite-water adsorption cooling unit, Applied Energy 88(11) (2011) 4206-4213.

[5] B.B. Saha, I.I. El-Sharkawy, A. Chakraborty, S. Koyama, Study on an activated carbon fiber-ethanol adsorption chiller: Part I-system description and modeling, International Journal of Refrigeration 30 (2007) 86-95.

[6] B.B. Saha, I.I. El-Sharkawy, A. Chakraborty, S. Koyama, Study on an activated carbon fiber-ethanol adsorption chiller: Part II- performance evaluation”, International Journal of Refrigeration 30 (2007) 96-102.

[7] E.E. Anyanwu, C.I. Ezekwe, Design, construction and test run of a solid adsorptionsolar refrigerator using activated carbon/methanol as adsorbent/adsorbate pair, Energy Conversion Management, 44 (18) (2003) 2879-2892. 
[8] D.J. Miles, S.V. Shelton, Design and testing of a solid sorption heat pump system, Applied Thermal Engineering, 16 (5) (1996) 389-394.

[9] K. Habib, B.B. Saha, Performance evaluation of solar driven activated carbon fiber-ethanol based adsorption cooling system in Malaysia, Asian Journal of Scientific Research 6(3) (2013) 146-156.

[10] A. El Fadar, A. Mimet, A. Azzabakh, M. Perez-Garcia, J. Castaing, Study of a new solar adsorption refrigerator system powered by a parabolic trough collector, Applied Thermal Engineering 29 (2009) 1267-1270.

[11] K. Habib, B.B. Saha, A. Chakraborty, S.T. Oh, S. Koyama, Study on solar driven combined adsorption refrigeration cycles in tropical climates, Applied Thermal Engineering 50(2013) 1582-1589.

[12] K. Habib, B. Choudhury, P.K. Chatterjee, B.B. Saha, Study on a solar heat driven dualmode adsorption chiller, Energy 63(2013) 133-141.

[13]Z. Lu, R. Wang, Z. Xia, Experimental analysis of an adsorption air-conditioning with microporous silica gel, Applied Thermal Engineering 50(2013) 1015-1020.

[14]X.Q. Zhai, R.Z. Wang, J.Y. Wu, Y.J. Dai, Q. Ma, Design and performance of a solarpowered air-conditioning system in a green building, Applied Energy 85(2008) 297-311.

[15] Z.S. Lu, R.Z. Wang, Z.Z. Xia, Q.B. Wu, Y.M. Sun, Z.Y. Chen, An analysis of the performance of a novel solar silica gel-water adsorption air-conditioning, Applied Thermal Engineering 31(2011) 3636-3642.

[16] K.C.A. Alam, B.B. Saha, A. Akisawa, Adsorption cooling driven by solar collector: A case study for Tokyo solar data, Applied Thermal Engineering 50 (2013) 1603-1609. 
[17] H.Z. Hassan, A.A. Mohamad, Thermodynamic analysis and theoretical study of a continuous operation solar-powered adsorption refrigeration system, Energy 61(2013) 167-178.

[18] H.R. Ramji, S.L. Leo, M.O. Abdullah, Parametric study and simulation of a heat-driven adsorber for air-conditioning system employing activated carbon-methanol working pair, Applied Energy 113(2014) 324-333.

[19] A. Mahesh, S.C. Kaushik, Solar adsorption refrigeration system using different mass of adsorbents, Journal of Thermal Analysis and Calorimetry 111(2013) 897-303.

[20] H.Z. Hassan, A.A. Mohamad, R. Bennacer, Simulation of an adsorption solar cooling system, Energy 36 (2011) 530-537.

[21] M. Pons, J.J. Guilleminot, Design of an experimental solar powered, solid adsorption ice maker, Journal of Solar Energy Engineering (Trans. ASME) 103(4) (1986) 332-337.

[22] E.E. Anyanwu, N.V. Ogueke, Transient analysis and performance prediction of a solid adsorption solar refrigerator, Applied Thermal Engineering 27 (2007) 2514-2523.

[23] K. Sumathy, H.L. Yong, M. Steinhagen, H. Kerskes, Performance analysis of a modified two-bed solar adsorption air-conditioning system, International Journal of Energy Research 33(2009) 675-686.

[24] Y.J. Dai, K. Sumathy, Heat and mass transfer in the adsorbent of a solar adsorption cooling system with glass tube insulation, Energy 28(2003) 1511-1527.

[25] Y. Hamamoto, K.C.A. Alam, B.B. Saha, S. Koyama, A. Akisawa, T. Kashiwagi, Study on adsorption refrigeration cycle utilizing activated carbon fibers. Part 1. Adsorption characteristics, International Journal of Refrigeration 29 (2006) 305-314. 
[26] E.F. Passos, J.F. Escobedo, F. Meunier, Simulation of an intermittent adsorptive solar cooling system, Solar Energy 42(1989) 103-111.

[27] B.B. Saha, E. Boelman, and T. Kashiwagi, Computer simulation of a silica gel water adsorption refrigeration cycle - the influence of operating conditions on cooling output and COP, ASHRAE Transactions, 101 (1995) 348-357.

[28] Y. Zhao, E. Hu, A. Blazewicz, A comparison of three adsorption equations and sensitivity study of parameter uncertainty effects on adsorption refrigeration thermal performance estimation, Heat Mass Transfer 48(2012) 217-226.

[29] C.K. Tang, Chapter 2-Malaaysia's weather data, http://bseep.weebly.com/uploads/8/0/7/2/8072374/chapter_2_malaysia_weather_data_draft 01.pdf 


\section{Table captions}

Table 1. Summary of solar driven adsorption cycles for cooling application.

Table 2. Porous properties of silica gel, ACF and AC.

Table 3. Adsorption parameter of silica gel-water, ACF-ethanol and AC-methanol pairs.

Table 4. Rated conditions.

Table 4. Values adopted for simulation. 
Table 1. Summary of solar driven adsorption cycles for cooling application.

\begin{tabular}{|c|c|c|c|}
\hline $\begin{array}{l}\text { Adsorbent- } \\
\text { refrigerant pair(s) }\end{array}$ & System description & System performance & Source \\
\hline $\begin{array}{l}\text { Activated carbon } \\
\text { fiber-ethanol }\end{array}$ & $\begin{array}{l}\text { A theoretical analysis of } \\
\text { a two-bed adsorption } \\
\text { chiller for Malaysian } \\
\text { climate }\end{array}$ & $\begin{array}{l}\text { A cooling capacity of } 12 \mathrm{~kW} \\
\text { can be achieved when the heat } \\
\text { source temperature is } 85^{\circ} \mathrm{C} \text {. }\end{array}$ & Habib and Saha [9] \\
\hline $\begin{array}{l}\text { Activated carbon- } \\
\text { ammonia }\end{array}$ & $\begin{array}{l}\text { Adsorption refrigeration } \\
\text { system powered by } \\
\text { parabolic trough solar } \\
\text { collector coupled with a } \\
\text { heat pipe }\end{array}$ & $\begin{array}{l}\text { Use of concentrated collector } \\
\text { and high flux density made the } \\
\text { system more compact and } \\
\text { lighter compared to the } \\
\text { systems with flat plate or } \\
\text { evacuated tube collectors }\end{array}$ & El Fadar el al. [10] \\
\hline $\begin{array}{l}\text { Activated carbon- } \\
\text { R134a }+ \\
\text { Activated carbon- } \\
\text { R507A }\end{array}$ & $\begin{array}{l}\text { Solar driven combined } \\
\text { adsorption refrigeration } \\
\text { cycle with AC-R134a as } \\
\text { topping cycle and AC- } \\
\text { R507A as bottoming } \\
\text { cycle }\end{array}$ & $\begin{array}{l}\text { The system can achieve a } \\
\text { refrigeration load }-10^{\circ} \mathrm{C} \text {. }\end{array}$ & Habib et al. [11] \\
\hline Silica gel-water & $\begin{array}{l}\text { A solar heat driven dual } \\
\text { mode chiller able to } \\
\text { provide cooling } \\
\text { throughout the year }\end{array}$ & $\begin{array}{l}\text { For a driving source } \\
\text { temperature above } 60^{\circ} \mathrm{C} \text {, the } \\
\text { chiller works as a single stage } \\
\text { four-bed adsorption chiller; } \\
\text { while the chiller functions as a } \\
\text { two stage adsorption chiller } \\
\text { when the driving source } \\
\text { temperature falls }\end{array}$ & Habib et al. [12] \\
\hline
\end{tabular}




\begin{tabular}{|c|c|c|c|}
\hline & & below $60^{\circ} \mathrm{C}$. & \\
\hline Silica gel-water & $\begin{array}{l}\text { One novel heat pipe } \\
\text { solar adsorption chiller } \\
\text { with mass-heat recovery } \\
\text { was designed. With } 65 \\
\text { kg of micro-porous } \\
\text { silica gel was used as } \\
\text { adsorbent in each } \\
\text { adsorbent bed. The } \\
\text { chiller was applied in } \\
\text { Green Building in } \\
\text { Dezhou city, China }\end{array}$ & $\begin{array}{l}\text { The average thermal efficiency } \\
\text { of solar collector, the average } \\
\text { COP of the adsorption } \\
\text { refrigerator and the average } \\
\text { solar COP of the system are } \\
0.36,0.44 \text { and } 0.16 \text {, } \\
\text { respectively }\end{array}$ & Lu et al. [13] \\
\hline Silica gel-water & $\begin{array}{l}\text { Solar powered air } \\
\text { conditioning system } \\
\text { which consisted of a } 150 \\
\mathrm{~m}^{2} \text { solar collector and } \\
\text { two adsorption chillers } \\
\text { with a capacity of } 8.5 \\
\mathrm{~kW} \text { each under the } \\
\text { typical weather } \\
\text { condition of Shanghai }\end{array}$ & $\begin{array}{l}\mathrm{COP}_{\text {solar }}=0.15 \\
\mathrm{COP}_{\text {system }}=0.35\end{array}$ & Zhai et al. [14] \\
\hline Silica gel-water & $\begin{array}{l}\text { The chiller with self- } \\
\text { balance of refrigerant is } \\
\text { investigated. The } \\
\text { performance of the } \\
\text { chiller may be } \\
\text { influenced by different } \\
\text { heating strategy. }\end{array}$ & $\begin{array}{l}\text { The cooling capacity and COP } \\
\text { obtained was } 3.6 \mathrm{~kW} \text { and } 0.32 \\
\text { when driving source } \\
\text { temperature, cooling water } \\
\text { inlet and chilled water inlet } \\
\text { temperatures were } 57^{\circ} \mathrm{C}, 27^{\circ} \mathrm{C} \\
\text { and } 15^{\circ} \mathrm{C} \text {, respectively. }\end{array}$ & Lu et al. [15] \\
\hline Silica gel-water & $\begin{array}{l}\text { An analytical } \\
\text { investigation has been } \\
\text { performed to study the }\end{array}$ & $\begin{array}{l}\text { At least } 15 \text { collector (each of } \\
2.415 \mathrm{~m}^{2} \text { ) is required to } \\
\text { achieve the required heat }\end{array}$ & Alam et al. [16] \\
\hline
\end{tabular}




\begin{tabular}{|c|c|c|c|}
\hline & $\begin{array}{l}\text { possibility of application } \\
\text { of solar cooling for } \\
\text { the climatic condition of } \\
\text { Tokyo, Japan. }\end{array}$ & $\begin{array}{l}\text { source temperature (around } \\
85^{\circ} \mathrm{C} \text { ) to run the cooling unit. } \\
\text { It is also observed that the } \\
\text { solar powered adsorption } \\
\text { cooling unit provides cooling } \\
\text { capacity around } 10 \mathrm{~kW} \text { at noon } \\
\text { with base run conditions, while } \\
\text { the system provides solar COP } \\
\text { around } 0.3 \text {. }\end{array}$ & \\
\hline $\begin{array}{l}\text { Activated carbon- } \\
\text { methanol }\end{array}$ & $\begin{array}{l}\text { A solar powered } \\
\text { theoretical adsorption } \\
\text { cooling system is } \\
\text { introduced which is able } \\
\text { to produce cold } \\
\text { continuously about } 24-\mathrm{h} \\
\text { of the day }\end{array}$ & $\begin{array}{l}\text { The chiller is able to produce a } \\
\text { daily mass of } 2.63 \mathrm{~kg} \text { of cold } \\
\text { water at } 0^{\circ} \mathrm{C} \text { from water at } \\
25^{\circ} \mathrm{C} \text { per } \mathrm{kg} \text { of adsorbent. COP } \\
\text { obtained was } 0.66 .\end{array}$ & $\begin{array}{l}\text { Hassan and Mohamad } \\
\text { [17] }\end{array}$ \\
\hline $\begin{array}{l}\text { Activated carbon- } \\
\text { methanol }\end{array}$ & $\begin{array}{l}\text { A parametric study } \\
\text { adsorption air- } \\
\text { conditioning system } \\
\text { employing } \\
\text { computational fluid } \\
\text { dynamics (CFD) } \\
\text { technique }\end{array}$ & $\begin{array}{l}\text { In CFD study, an input exhaust } \\
\text { gas of } 200^{\circ} \mathrm{C} \text { would have bed } \\
\text { temperature of } 120^{\circ} \mathrm{C} \text { while } \\
\text { employing } 20 \mathrm{~mm} \text { tick of wall } \\
\text { made of stainless steel. }\end{array}$ & Ramji et al. [18] \\
\hline $\begin{array}{l}\text { Activated carbon- } \\
\text { methanol }\end{array}$ & $\begin{array}{l}\text { A prototype model of } \\
\text { solar adsorption } \\
\text { refrigeration system was } \\
\text { constructed and its } \\
\text { performance was } \\
\text { evaluated with different } \\
\text { mass ratios ranging from } \\
0.25-2.50 \text { of adsorbent }\end{array}$ & $\begin{array}{l}\text { When mass ratio is } 1.0, \mathrm{a} \\
\text { minimum cooling temperature } \\
\text { of } 12.2^{\circ} \mathrm{C} \text { was obtained. }\end{array}$ & $\begin{array}{l}\text { Mahesh and Kaushik } \\
\text { [19] }\end{array}$ \\
\hline
\end{tabular}




\begin{tabular}{|c|c|c|c|}
\hline $\begin{array}{l}\text { Activated carbon- } \\
\text { methanol }\end{array}$ & $\begin{array}{l}\text { A theoretical analysis of } \\
\text { a tubular solar } \\
\text { adsorption refrigeration } \\
\text { system which takes into } \\
\text { account the variations of } \\
\text { ambient temperature and } \\
\text { solar radiation along the } \\
\text { day }\end{array}$ & $\begin{array}{l}\text { COP and SCP obtained are } \\
0.211 \text { and } 2,326 \mathrm{~kW} \text {, } \\
\text { respectively. Pressure } \\
\text { distribution inside the } \\
\text { adsorption bed was found } \\
\text { nearly uniform and varying } \\
\text { with time. }\end{array}$ & Hassan et al. [20] \\
\hline $\begin{array}{l}\text { Activated carbon- } \\
\text { methanol }\end{array}$ & $\begin{array}{l}\text { Solar adsorption } \\
\text { refrigeration system to } \\
\text { produce ice }\end{array}$ & $\begin{array}{l}\text { Ice at }-3^{\circ} \mathrm{C} \text { was produced at } \\
\text { the rate of about } 6 \mathrm{~kg} \text { per } \mathrm{m}^{2} \text { of } \\
\text { collector area. } \\
\mathrm{COP}_{\text {solar }}=0.12 \\
\mathrm{COP}_{\text {system }}=0.43\end{array}$ & $\begin{array}{l}\text { Pons and Guilleminot } \\
\text { [21] }\end{array}$ \\
\hline $\begin{array}{l}\text { Activated carbon- } \\
\text { methanol }\end{array}$ & $\begin{array}{l}\text { A finite element based } \\
\text { transient analysis of a } \\
\text { solar powered } \\
\text { adsorption refrigerator }\end{array}$ & $\begin{array}{l}\text { Numerically the performance } \\
\text { of the refrigerator improved } \\
\text { with the decrease in condenser } \\
\text { pressure and increase in } \\
\text { evaporator pressure }\end{array}$ & $\begin{array}{l}\text { Anynawu and Ogueke } \\
{[22]}\end{array}$ \\
\hline $\begin{array}{l}\text { Activated carbon- } \\
\text { methanol }\end{array}$ & $\begin{array}{l}\text { Lumped parameter } \\
\text { analysis of an adsorption } \\
\text { air-conditioning } \\
\text { system driven by simple } \\
\text { flat-plate solar } \\
\text { collectors }\end{array}$ & $\begin{array}{l}\text { Optimum values of adsorbent } \\
\text { mass and collector area to get a } \\
\text { maximum SCP of } 150 \mathrm{Wm}^{-2}\end{array}$ & Sumathy et al. [23] \\
\hline $\begin{array}{l}\text { Activated carbon- } \\
\text { methanol }\end{array}$ & $\begin{array}{l}\text { Performance of a solar } \\
\text { adsorption cooling } \\
\text { system with tubular } \\
\text { adsorber in evacuated } \\
\text { glass tube insulation }\end{array}$ & $\begin{array}{l}\text { No significant pressure } \\
\text { difference in the } 80 \mathrm{~mm} \\
\text { diameter adsorber tubes during } \\
\text { the heating period }\end{array}$ & Dai and Sumathy [24] \\
\hline
\end{tabular}


Table 2. Porous properties of silica gel, ACF and AC.

\begin{tabular}{|l|c|c|c|l|}
\hline Adsorbent & $\begin{array}{c}\text { Surface area } \\
\left(\mathrm{m}^{2} \mathrm{~g}^{-1}\right)\end{array}$ & $\begin{array}{c}\text { Pore volume } \\
\left(\mathrm{ccg}^{-1}\right)\end{array}$ & $\begin{array}{c}\text { Apparent density } \\
\left(\mathrm{kgm}^{-3}\right)\end{array}$ & Source \\
\hline Silica gel (type A) & 715 & 0.28 & 730 & Chua et al. [1] \\
\hline ACF (A-20) & 1900 & 1.028 & 300 & $\begin{array}{l}\text { Hamamoto et al } \\
{[25]}\end{array}$ \\
\hline AC & 1450 & 0.5 & 350 & $\begin{array}{l}\text { Hamamoto et al. } \\
{[25]}\end{array}$ \\
\hline
\end{tabular}


Table 3. Adsorption characteristics of silica gel-water, ACF-ethanol and AC-methanol pairs.

\begin{tabular}{|l|l|l|}
\hline Silica gel-water pair [2] & $\alpha_{0}$ & $-6.5314 \mathrm{~kg}(\mathrm{~kg} \text { of dry adsorbent })^{-1}$ \\
\cline { 2 - 3 } & $\alpha_{1}$ & $0.72452 \times 10^{-1} \mathrm{~kg}(\mathrm{~kg} \text { of dry adsorbent, })^{-1}$ \\
\cline { 2 - 3 } & $\alpha_{2}$ & $-0.23951 \times 10^{-3} \mathrm{~kg}\left(\mathrm{~kg} \text { of dry adsorbent, } \mathrm{K}^{2}\right)^{-1}$ \\
\cline { 2 - 3 } & $\alpha_{3}$ & $0.25493 \times 10^{-6} \mathrm{~kg}\left(\mathrm{~kg} \text { of dry adsorbent, } \mathrm{K}^{3}\right)^{-1}$ \\
\cline { 2 - 3 } & $\beta_{0}$ & -15.587 \\
\cline { 2 - 3 } & $\beta_{1}$ & $0.15915 \mathrm{~K}^{-1}$ \\
\cline { 2 - 3 } & $\beta_{2}$ & $-0.50612 \times 10^{-3} \mathrm{~K}^{-2}$ \\
\cline { 2 - 3 } & $\beta_{3}$ & $0.5329 \times 10^{-6} \mathrm{~K}^{-3}$ \\
\hline ACF-ethanol pair [5] & $\mathrm{x}_{0}$ & $0.797 \mathrm{~kg} \mathrm{ethanol} / \mathrm{kg} \mathrm{ACF}$ \\
\cline { 2 - 3 } & $D$ & $1.716 \times 10^{-6} \mathrm{~K}^{-2}$ \\
\hline AC-methanol pair [28] & $\mathrm{x}_{0}$ & $0.28 \mathrm{~kg} / \mathrm{kg}$ \\
\cline { 2 - 3 } & $D$ & $8.45 \times 10^{-7} \mathrm{~K}^{-2}$ \\
\cline { 2 - 3 } & $n$ & 2.08 \\
\hline
\end{tabular}




\begin{tabular}{|c|c|c|c|c|c|c|}
\hline \multirow{2}{*}{$\begin{array}{c}\text { Adsorption } \\
\text { Cycle }\end{array}$} & $\begin{array}{c}\text { Temperature } \\
\left({ }^{\circ} \mathrm{C}\right)\end{array}$ & $\begin{array}{c}\text { Flow rate } \\
(\mathrm{kg} / \mathrm{s})\end{array}$ & $\begin{array}{c}\text { Temperature } \\
\left({ }^{\circ} \mathrm{C}\right)\end{array}$ & $\begin{array}{c}\text { Flow rate } \\
(\mathrm{kg} / \mathrm{s}) \\
(\mathrm{ads}+\mathrm{con})\end{array}$ & $\begin{array}{c}\text { Temperature } \\
\left({ }^{\circ} \mathrm{C}\right)\end{array}$ & $\begin{array}{c}\text { Flow } \\
\text { rate } \\
(\mathrm{kg} / \mathrm{s})\end{array}$ \\
\hline $\begin{array}{c}\text { Silica gel- } \\
\text { water cycle }\end{array}$ & 85 & 1.5 & 30 & $(1.5+1.5)$ & 14 & 0.6 \\
\hline $\begin{array}{c}\text { ACF- } \\
\text { ethanol } \\
\text { cycle }\end{array}$ & 85 & 1.5 & 30 & $(1.5+1.5)$ & 14 & 0.6 \\
\hline $\begin{array}{c}\text { AC- } \\
\text { methanol } \\
\text { cycle }\end{array}$ & 85 & 1.5 & 30 & $(1.5+1.5)$ & 14 & 0.6 \\
\hline \multicolumn{2}{|c|}{ Adsorption/desorption cycle time: $500 \mathrm{~s}$} & \multicolumn{3}{|c|}{ Switching time for both cycles: $50 \mathrm{~s}$} \\
\hline
\end{tabular}

Table 4. Rated conditions. 
Table 5. Values adopted for simulation.

\begin{tabular}{|c|c|c|c|c|}
\hline Symbols & $\begin{array}{c}\text { Silica } \\
\text { gel-water }\end{array}$ & $\begin{array}{c}\text { AC- } \\
\text { methanol }\end{array}$ & $\begin{array}{c}\text { ACF- } \\
\text { ethanol }\end{array}$ & Unit \\
\hline$m_{a}$ & 40 & 40 & 40 & $\mathrm{~kg}$ \\
\hline$U A_{\text {bed }}$ & 3500 & 3600 & 3300 & $\mathrm{~W} / \mathrm{K}$ \\
\hline$U A_{\text {eva }}$ & 4870 & 4890 & 4860 & $\mathrm{~W} / \mathrm{K}$ \\
\hline$U A_{\text {con }}$ & 15330 & 15340 & 15320 & $\mathrm{~W} / \mathrm{K}$ \\
\hline$m_{\text {con }}$ & 24.28 & 25.28 & 23.28 & $\mathrm{~kg}$ \\
\hline$m_{\text {eva }}$ & 12.45 & 11.45 & 13.45 & $\mathrm{~kg}$ \\
\hline$C_{p, a}$ & 960 & 889 & 895 & $\mathrm{~J} / \mathrm{kg}-\mathrm{K}$ \\
\hline$h_{f g}$ & $2.8 \times 10^{6}$ & $1.15 \times 10^{6}$ & $2.0 \times 10^{6}$ & $\mathrm{~J} / \mathrm{kg}$ \\
\hline$C_{p, h e x}$ & 950 & 950 & 950 & $\mathrm{~J} / \mathrm{kg}-\mathrm{K}$ \\
\hline
\end{tabular}




\section{Figure captions}

Figure 1: Schematic diagram of the solar driven two-bed adsorption cooling cycle.

Figure 2: Hourly variation of solar radiation on a particular day in Kuala Lumpur.

Figure 3: Hourly variation of storage tank temperature on a particular day in Kuala Lumpur.

Figure 4: Adsorption isotherms for ACF-ethanol, silica gel-water and AC-methanol pairs.

Figure 5: Adsorption/desorption cycle time effect on cooling capacity for ACF-ethanol, silica gel-water and AC-methanol adsorption cycles.

Figure 6: Adsorption/desorption cycle time effects on COP for ACF-ethanol, silica gel-water and AC-methanol adsorption cycles.

Figure 7: Regeneration temperature effects on cooling capacity for zeolite-water [3], ACFethanol, silica gel-water and AC-methanol adsorption cycles.

Figure 8: Regeneration temperature effects on COP for zeolite-water 3], ACF-ethanol, silica gelwater and AC-methanol adsorption cycles.

Figure 9: Chilled water inlet temperature effects on cooling capacity for ACF-ethanol, silica gelwater and AC-methanol adsorption cycles.

Figure 10: Chilled water inlet temperature effects on COP for ACF-ethanol, silica gel-water and AC-methanol adsorption cycle. 


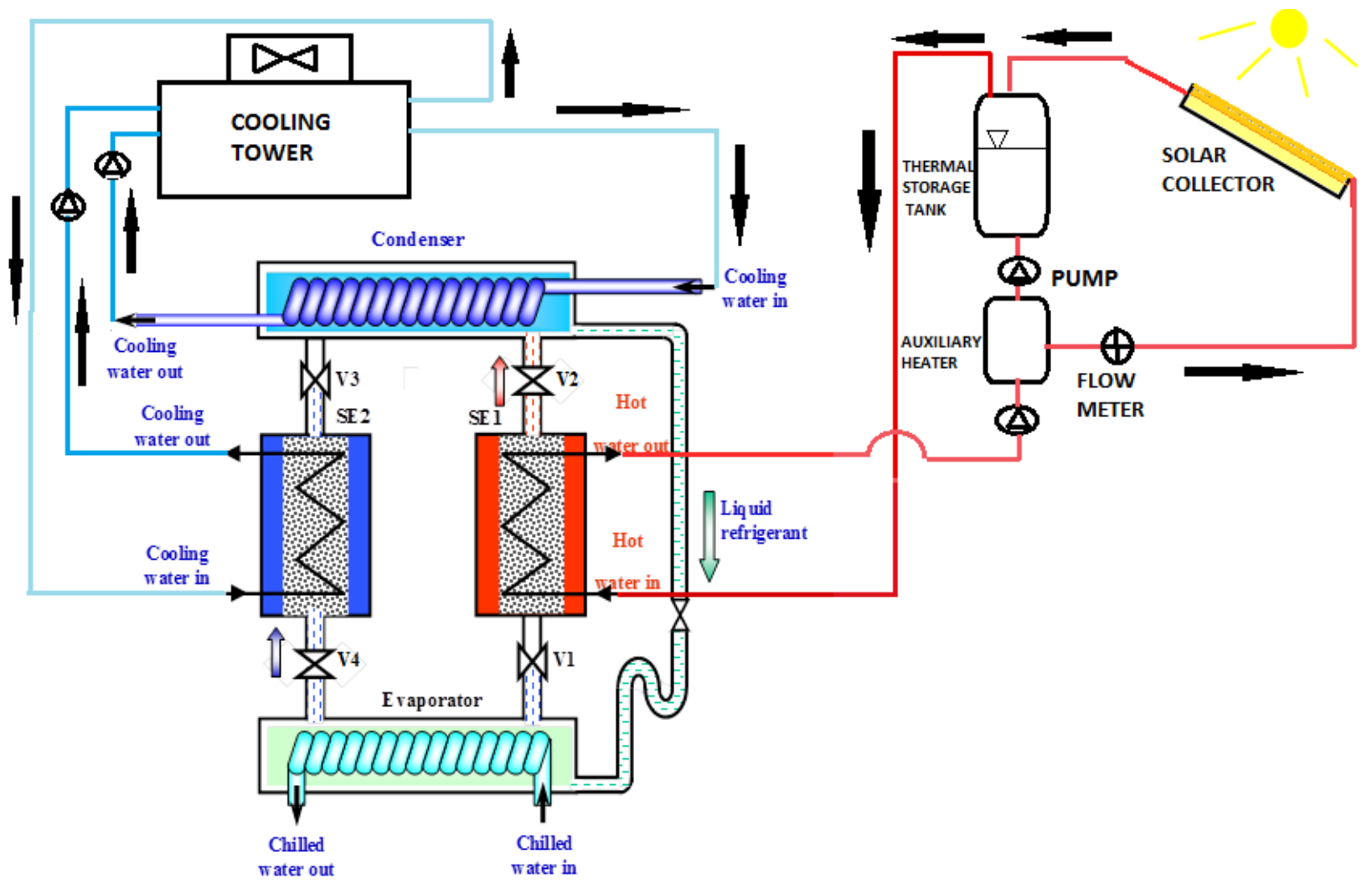

Figure 1 


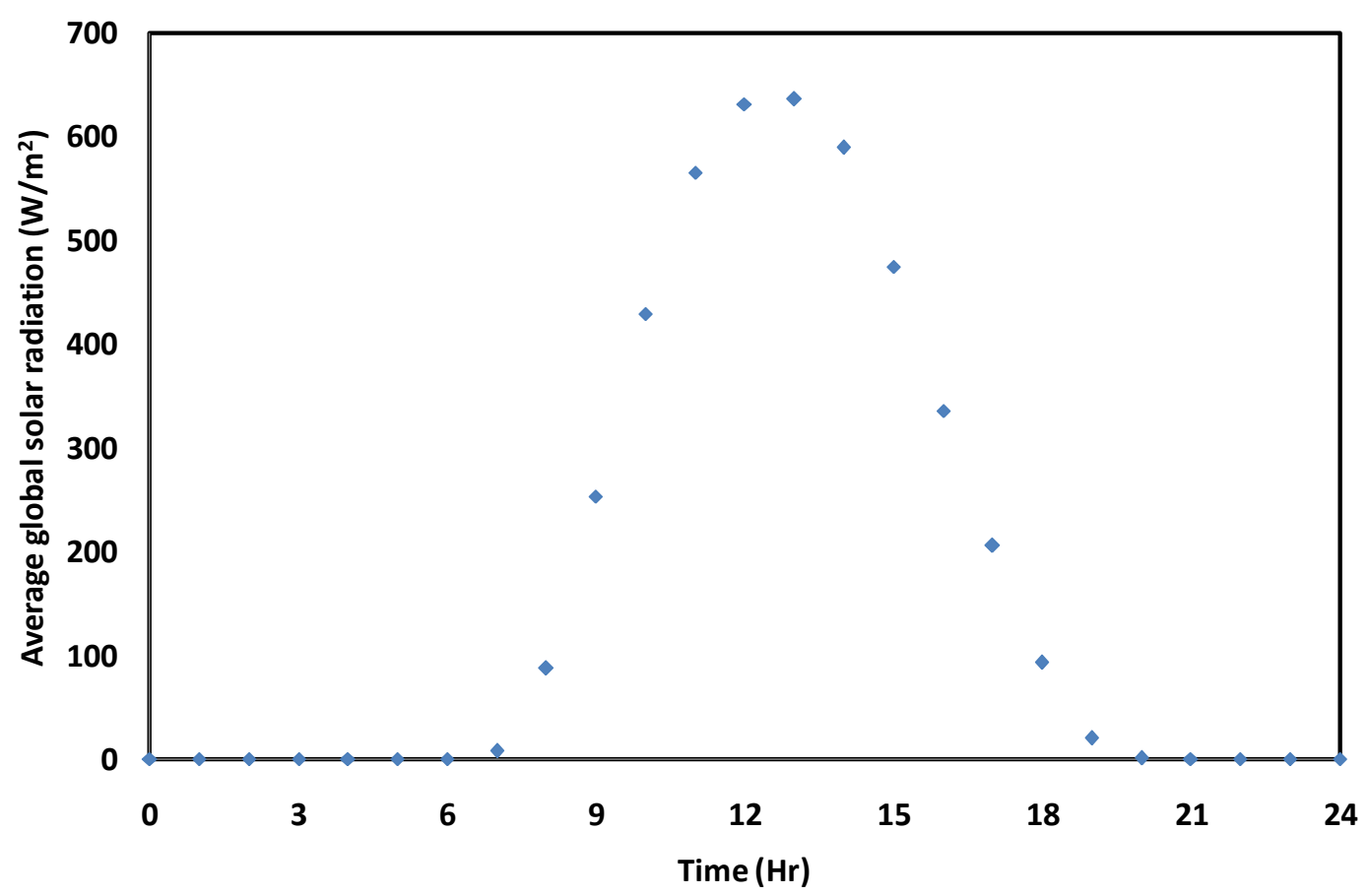

Figure 2 


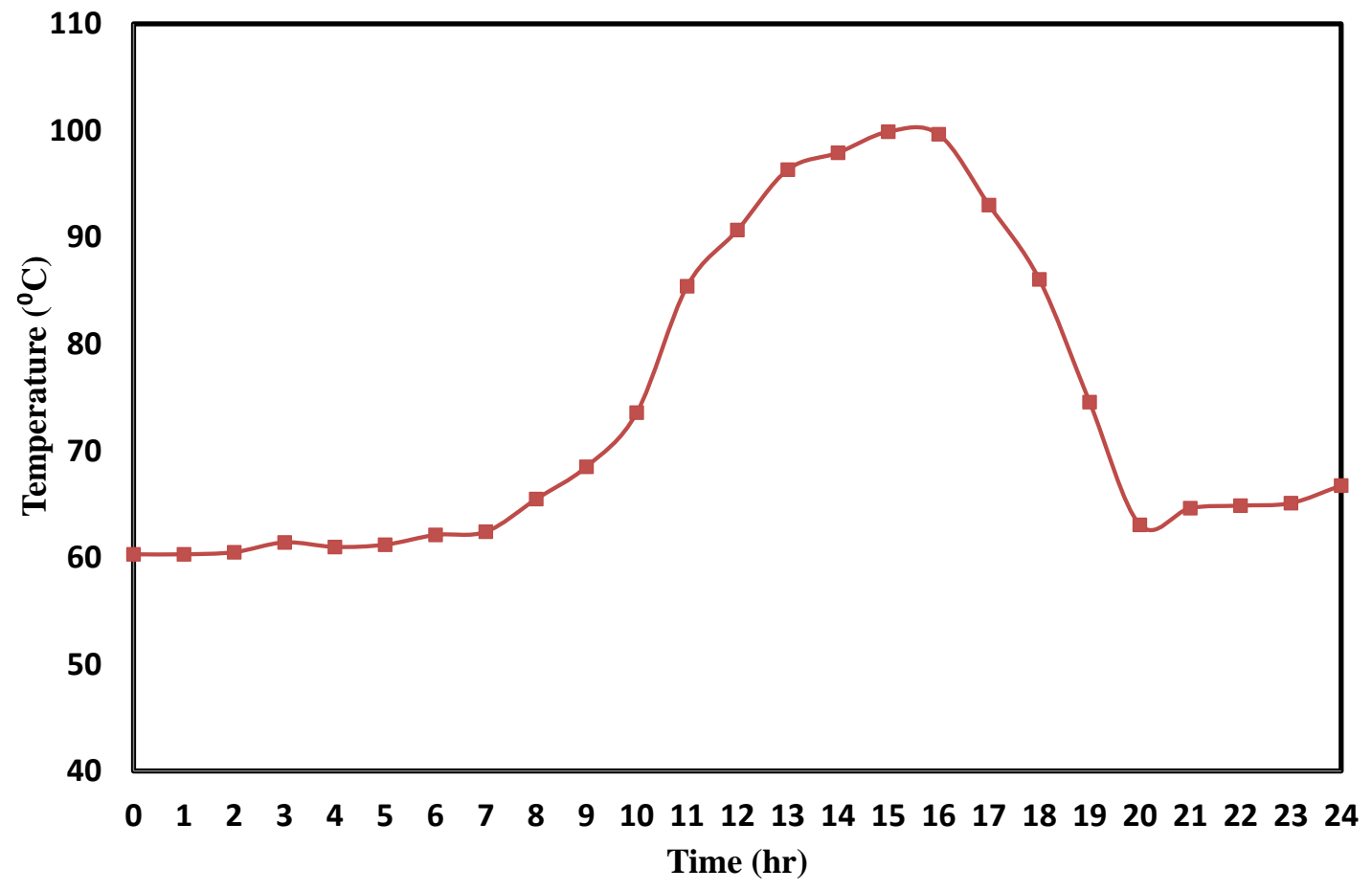

Figure 3 


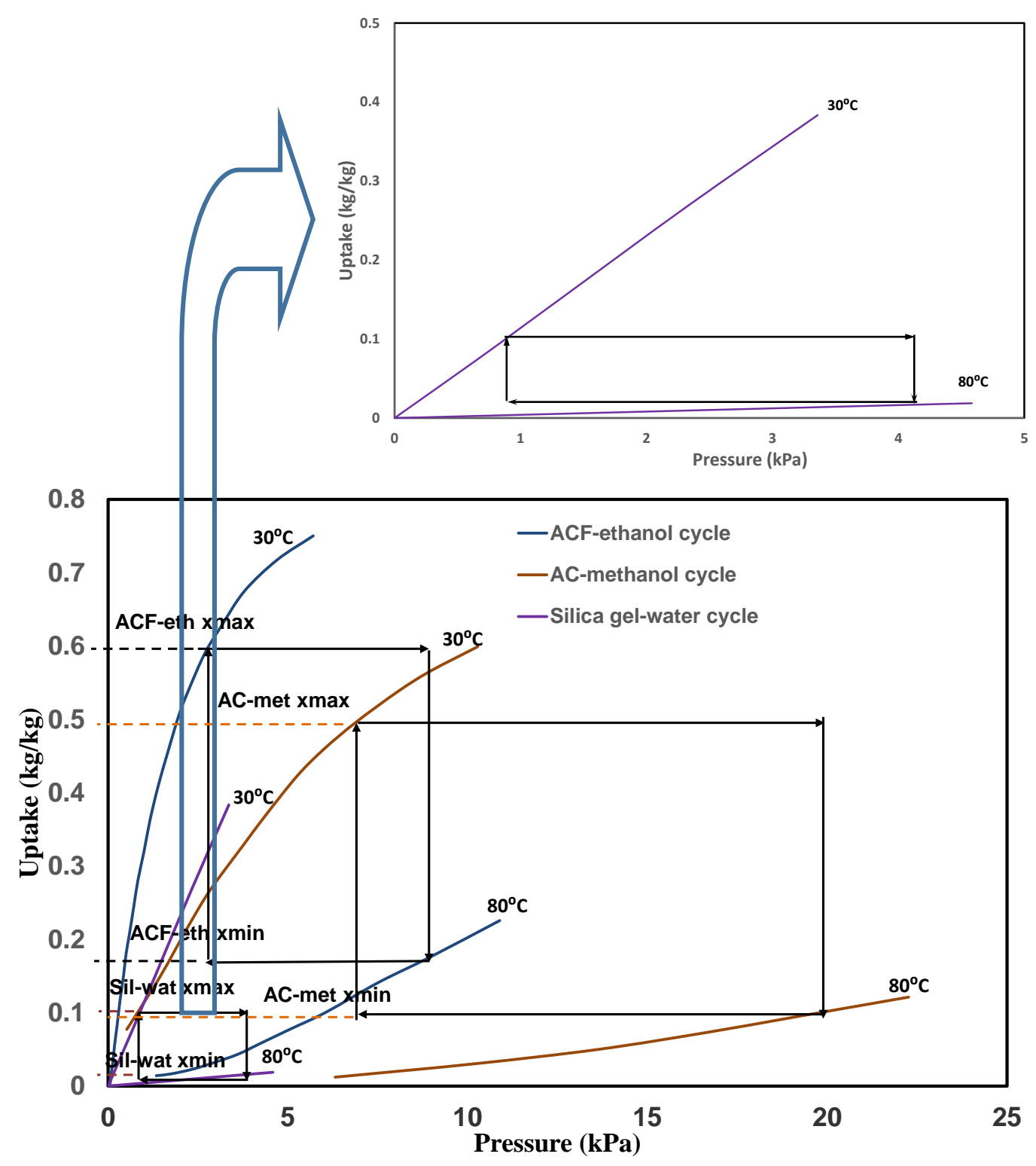

$\Delta x(\mathrm{ACF}-\mathrm{ethanol})=0.44 ; \Delta x(\mathrm{AC}-$ methanol $)=0.4 ; \Delta x($ Silica gel-water $)=0.08$

Figure 4 


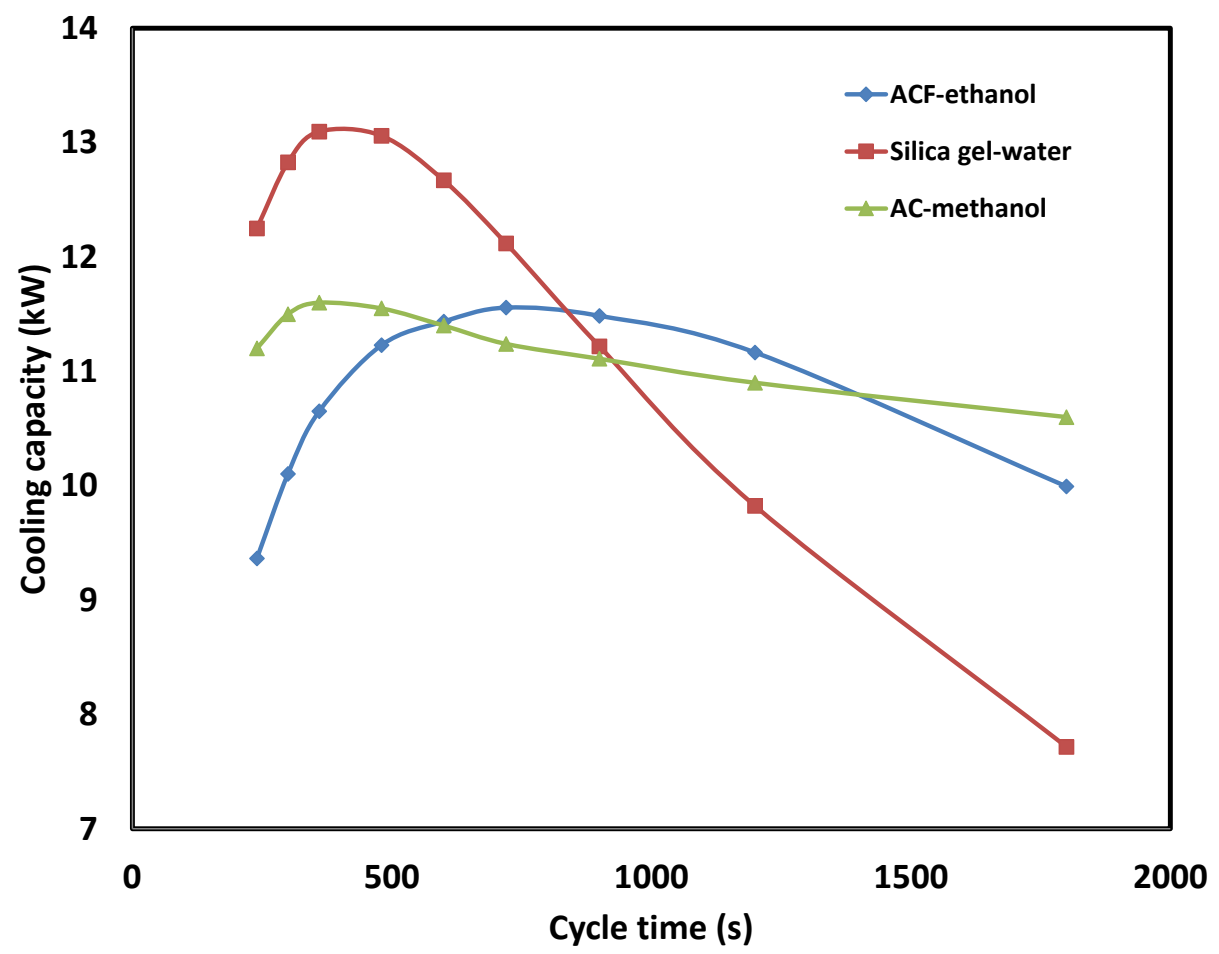

Figure 5 


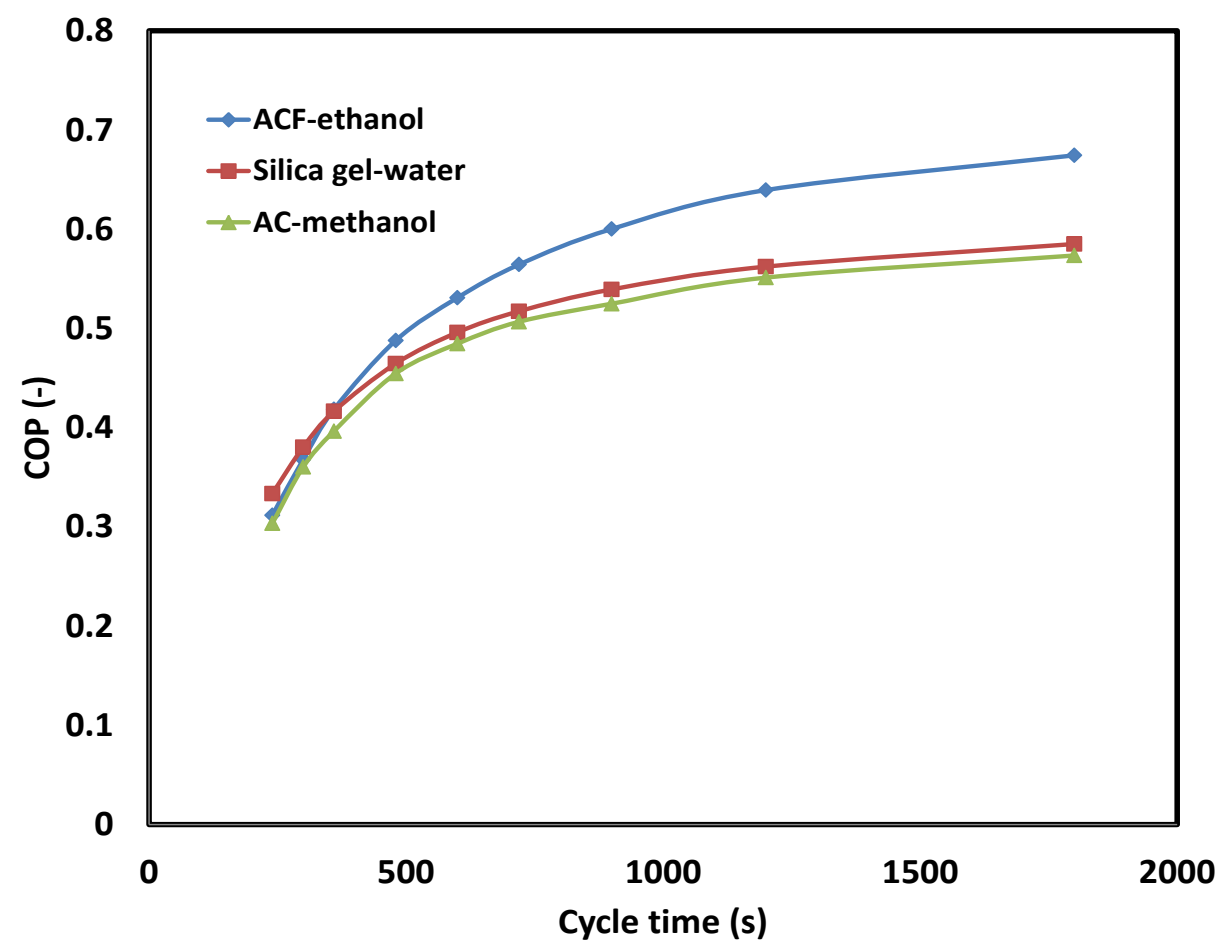

Figure 6 


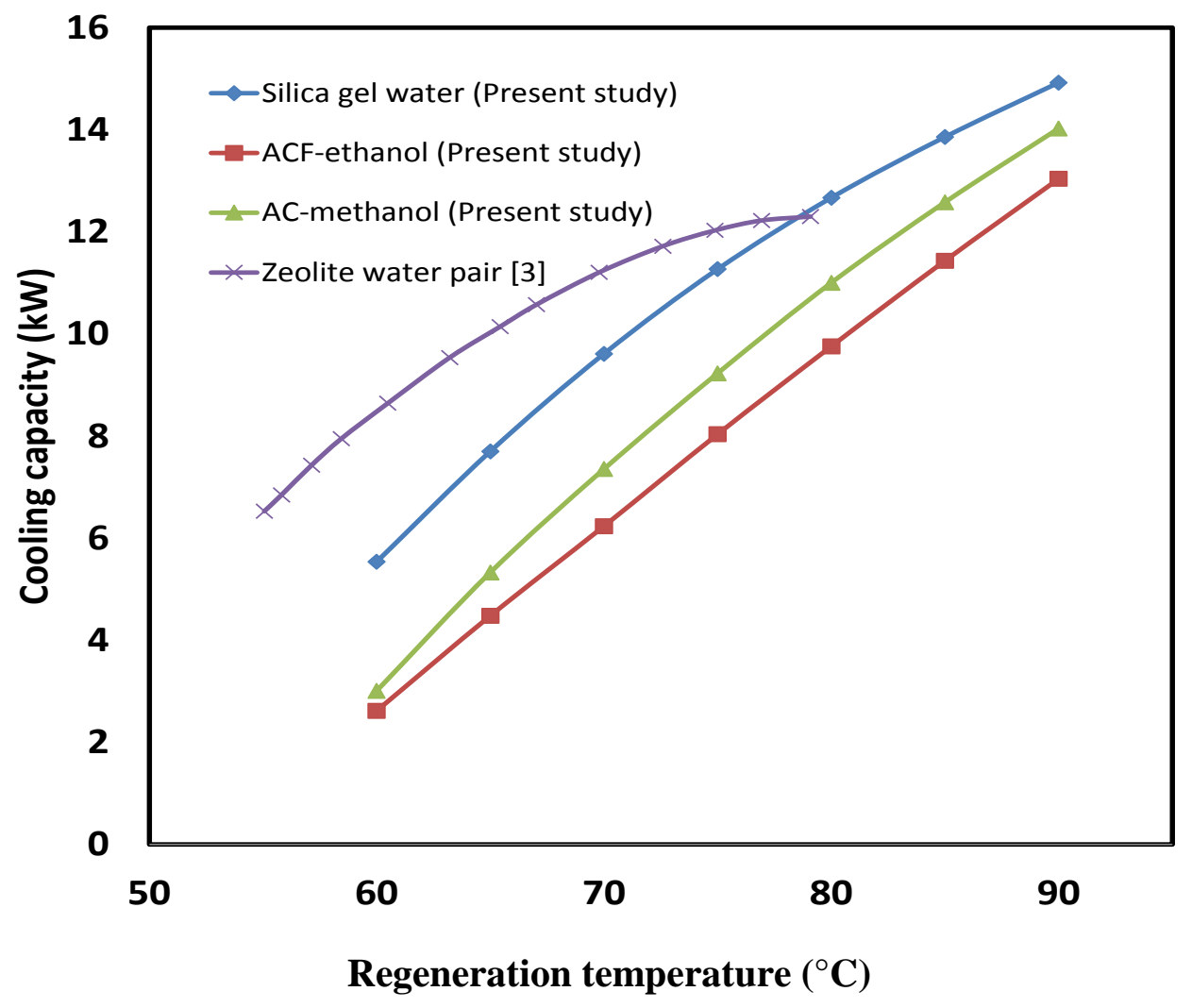

Figure 7 


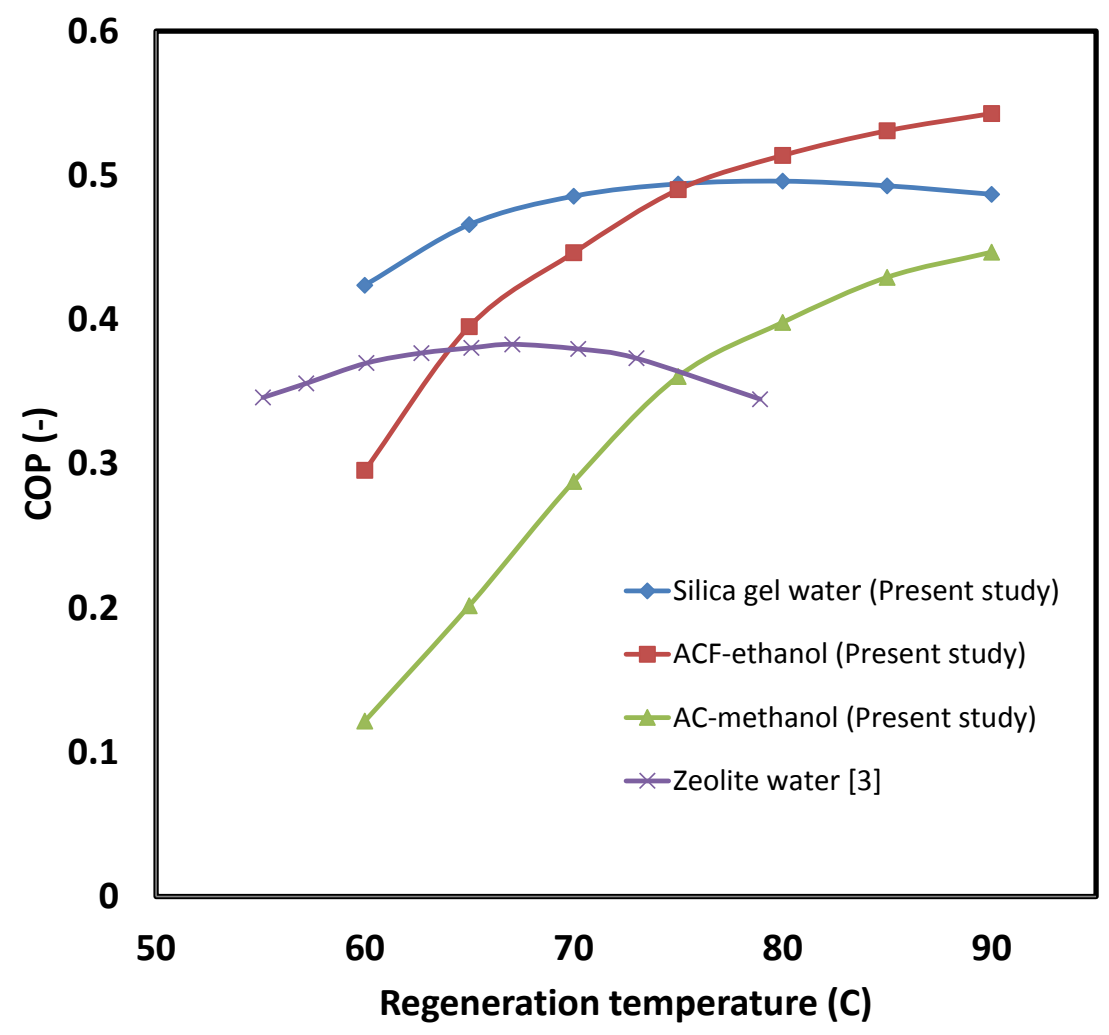

Figure 8 


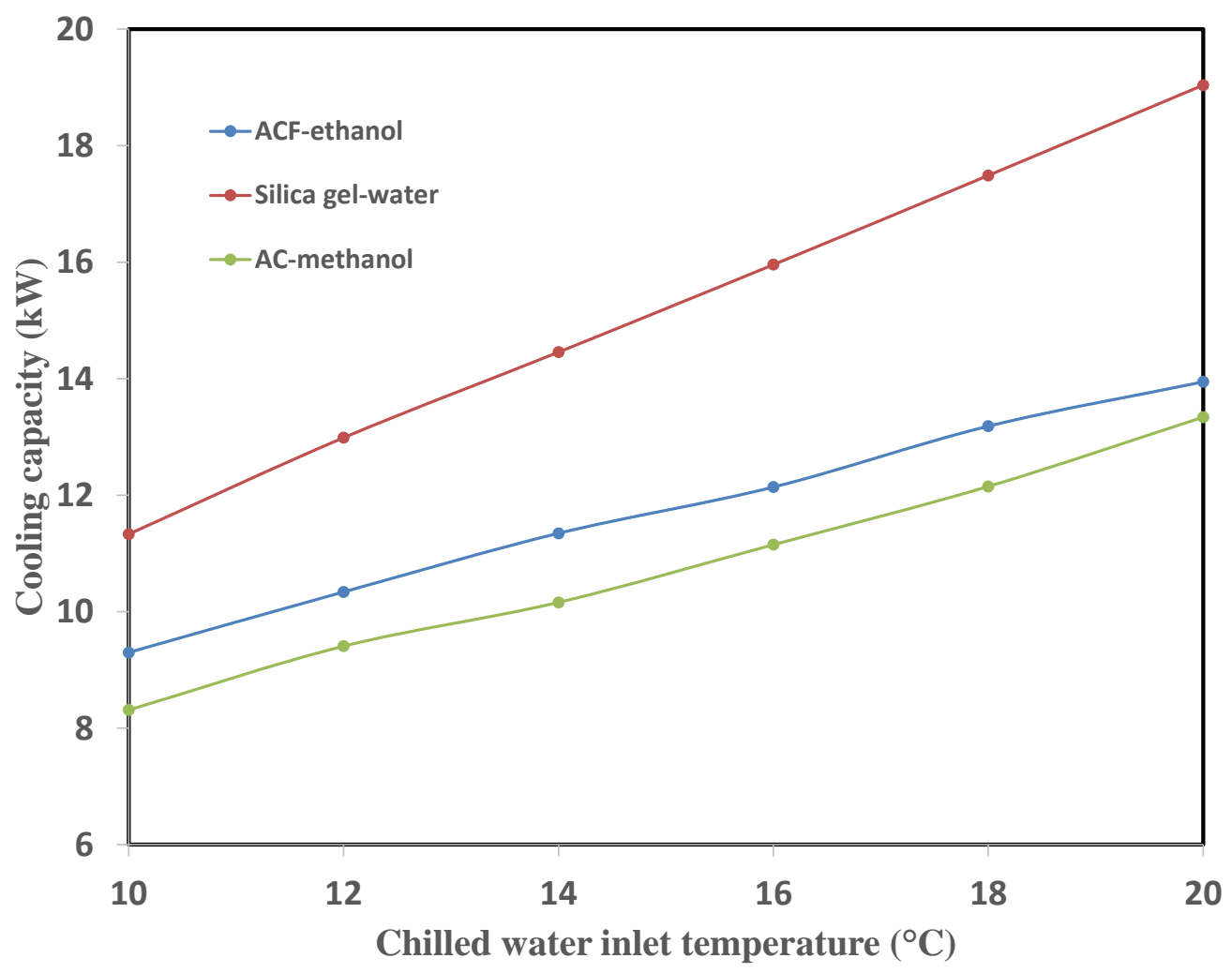

Figure 9 


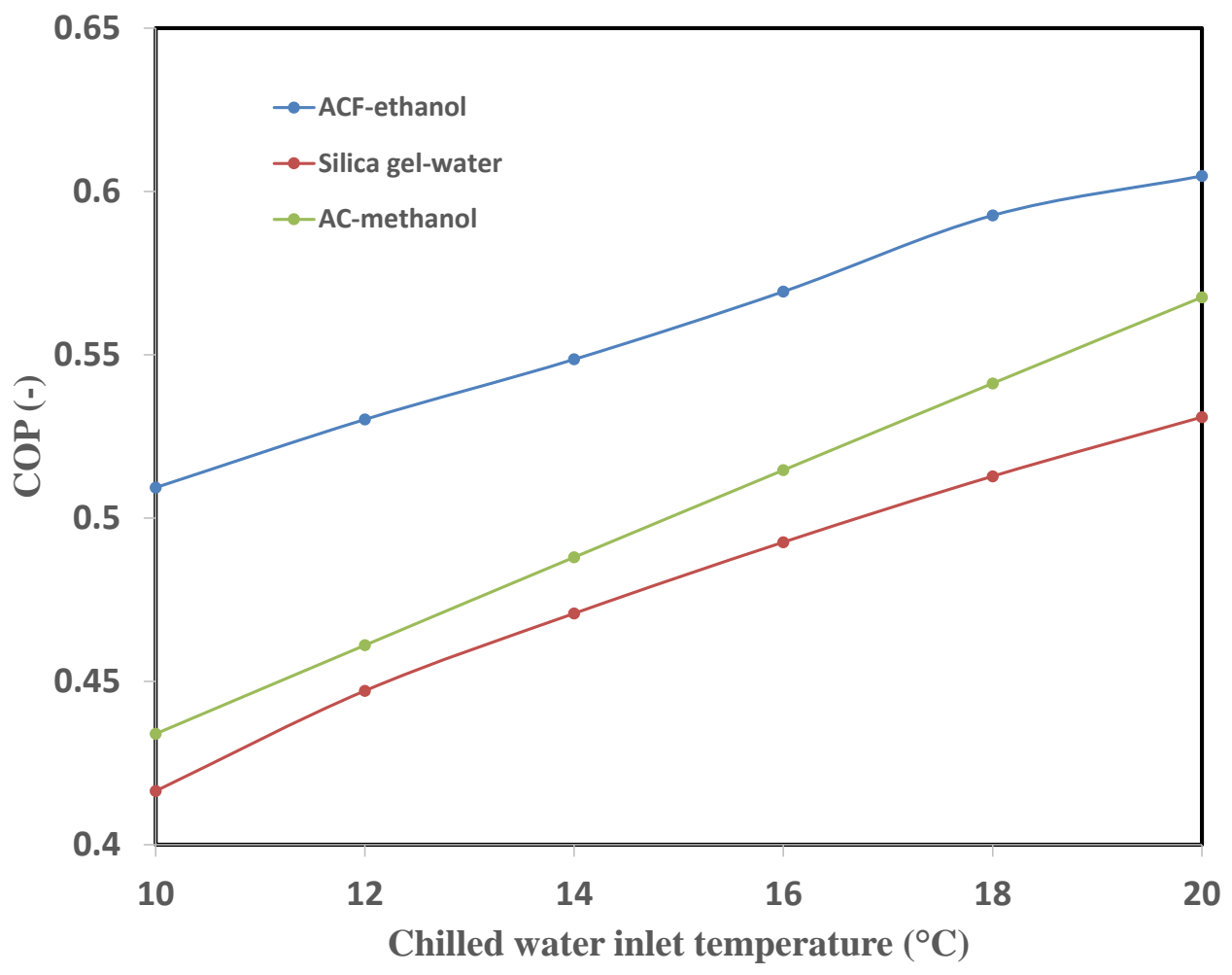

Figure 10 